\title{
Palladacyclic Conjugate Group Promotes Hybridization of Short Oligonucleotides
}

\author{
Madhuri Hande, Sajal Maity and Tuomas Lönnberg * (iD \\ Department of Chemistry, University of Turku, Vatselankatu 2, 20014 Turku, Finland; \\ nimamadhuri@gmail.com (M.H.); sajal.k.maity@utu.fi (S.M.) \\ * Correspondence: tuanlo@utu.fi; Tel.: +358-29-450-3191
}

Received: 18 May 2018; Accepted: 26 May 2018; Published: 28 May 2018

\begin{abstract}
Short oligonucleotides with cyclopalladated benzylamine moieties at their $5^{\prime}$-termini have been prepared to test the possibility of conferring palladacyclic anticancer agents sequence-selectivity by conjugation with a guiding oligonucleotide. Hybridization of these oligonucleotides with natural counterparts was studied by UV and CD (circular dichroism) melting experiments in the absence and presence of a competing ligand (2-mercaptoethanol). Cyclopalladated benzylamine proved to be strongly stabilizing relative to unmetalated benzylamine and modestly stabilizing relative to an extra A $\bullet \mathrm{T}$ base pair. The stabilization was largely abolished in the presence of 2-mercaptoethanol, suggesting direct coordination of $\mathrm{Pd}(\mathrm{II})$ to a nucleobase of the complementary strand. In all cases, fidelity of Watson-Crick base pairing between the two strands was retained. Hybridization of the cyclopalladated oligonucleotides was characterized by relatively large negative enthalpy and entropy, consistent with stabilizing $\mathrm{Pd}(\mathrm{II})$ coordination partially offset by the entropic penalty of imposing conformational constraints on the flexible diethylene glycol linker between the oligonucleotide and the palladacyclic moiety.
\end{abstract}

Keywords: DNA; oligonucleotide; hybridization; organometallic; palladacycle; palladium

\section{Introduction}

The groundbreaking discovery of the antitumor activity of cisplatin [1,2] has been followed by efforts to develop more potent anticancer agents based on transition metal complexes [3-11]. In particular, problems associated with the presently available platinum anticancer compounds, notably acquired or intrinsic resistance, limited spectrum of activity and relatively high degree of toxicity [12-14], have prompted interest in transition metals other than platinum for chemotherapeutic use $[4,6-8,15]$. Palladium is an attractive candidate because its coordination chemistry is similar to that of platinum [16,17]. Pd(II) complexes are, however, kinetically approximately five orders of magnitude more labile than the respective $\mathrm{Pt}(\mathrm{II})$ complexes [18]. While the relatively rapid ligand-exchange of $\mathrm{Pd}(\mathrm{II})$ should allow formation of thermodynamic (rather than kinetic) products and thus higher selectivity than attainable with $\mathrm{Pt}(\mathrm{II})$-based drugs, it is also likely to result in a different mode of action, at least with simple analogues [19]. No clinically approved palladium-containing drugs are presently available.

The possibility of using palladacyclic complexes as anticancer agents to circumvent the problems caused by the kinetic lability of $\operatorname{Pd}(\mathrm{II})$ has received attention over the past decade. The high stability of palladacyclic compounds in physiological media and the resultant low toxicity to normal cells make them promising candidates for future therapeutic agents $[9,20]$. The selectivity of these agents could be further improved by conjugation to a guiding oligonucleotide. The feasibility of this approach has already been demonstrated with a number of Pt(II)-carrying DNA and PNA oligonucleotides [21-26] but with palladacyclic modifications we are only aware of a single recent example, a short DNA 
oligonucleotide incorporating a single cyclopalladated phenylpyridine residue in the middle of the sequence [27]. In that case, coordination of $\mathrm{Pd}(\mathrm{II})$ to the opposite base on a complementary strand was inferred from the abnormally high UV and CD (circular dichroism) signals but the expected stabilization of the double helix by such coordination could not be demonstrated unambiguously. Possibly a stable Pd(II)-mediated base pair was formed but could not be readily accommodated within the base stack, leading to disruption of the double helix.

Herein we describe the synthesis and hybridization properties of short oligonucleotides incorporating cyclopalladated benzylamine "warheads" at their $5^{\prime}$-termini. At monomer level, palladacyclic benzylamine derivatives have already been found to exhibit antitumor activity [28,29]. The $5^{\prime}$-terminal position was chosen to avoid disruption of the double helix by suboptimal coordination geometry. For the same reason, a relatively long and flexible diethylene glycol spacer was used between the cyclopalladated benzylamine and the oligonucleotide.

\section{Results}

\subsection{Synthesis of the Benzylamine Phosphoramidite Building Block}

Synthesis of the protected phosphoramidite building block of benzylamine (1) is outlined in Scheme 1. First, benzyl bromide was allowed to react with an excess of 2-(2-aminoethoxy)ethanol to give 2-[2-(benzylamino)ethoxy] tethanol (2). The secondary amino function was then protected as a trifluoroacetamide by treatment with ethyl trifluoroacetate. Finally, the protected intermediate 3 was phosphitylated by conventional methods to afford the phosphoramidite building block 1 .

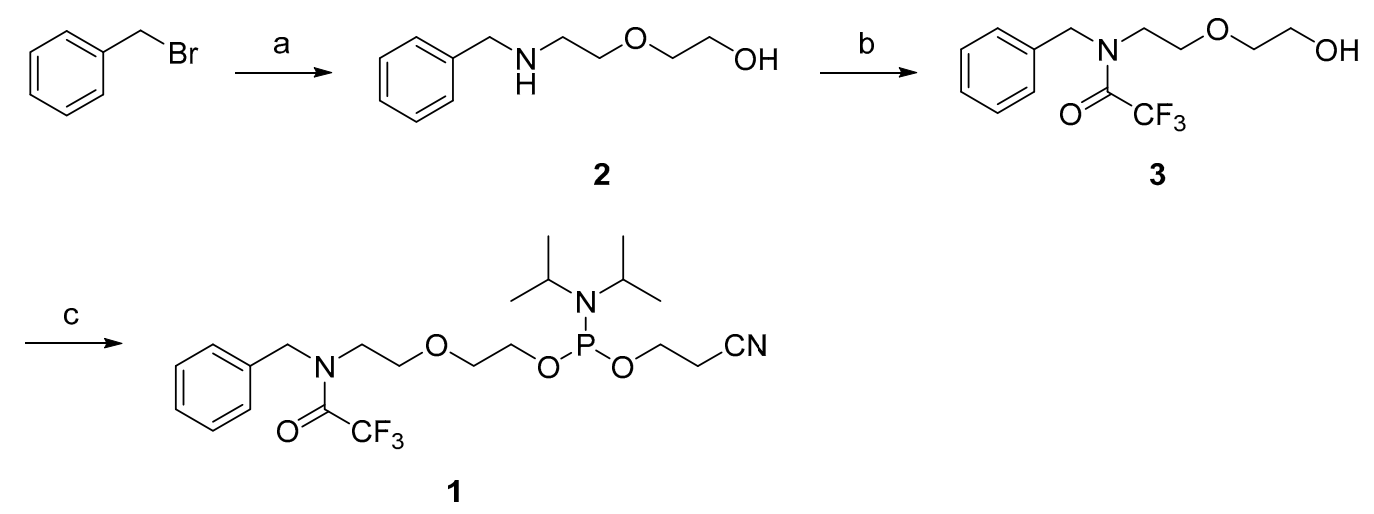

Scheme 1. Synthesis of the benzylamine phosphoramidite 1. Reagents and conditions: (a) 2-(2-aminoethoxy)ethanol, $\mathrm{MeCN}, 25{ }^{\circ} \mathrm{C}, 16 \mathrm{~h}$; (b) ethyl trifluoroacetate, $\mathrm{Et}_{3} \mathrm{~N}, \mathrm{MeOH}, 25{ }^{\circ} \mathrm{C}$, $16 \mathrm{~h}$; (c) 2-cyanoethyl-N,N-diisopropylchlorophosphoramidite, $\mathrm{Et}_{3} \mathrm{~N}, \mathrm{CH}_{2} \mathrm{Cl}_{2}, \mathrm{~N}_{2}$ atmosphere, $25^{\circ} \mathrm{C}, 3 \mathrm{~h}$.

\subsection{Cyclopalladation of 2-[2-(benzylamino)ethoxy]ethanol}

Cyclopalladation was first tested at monomer level with 2-[2-(benzylamino)ethoxy]ethanol (2) by treatment with an equimolar amount of lithium tetrachloropalladate in a mixture of water and acetonitrile. Near-quantitative conversion of the starting material was achieved overnight. ${ }^{1} \mathrm{H} \mathrm{NMR}$ (nuclear magnetic resonance) spectrum of the product revealed loss of one ortho proton of the phenyl ring and ${ }^{13} \mathrm{C}$ NMR spectrum a downfield shift of the respective carbon signal. Both results are consistent with replacement of the ortho proton with $\mathrm{Pd}(\mathrm{II})$. The most likely structure of the product is the chlorido-bridged dimer 4 (Scheme 2), as reported previously on related compounds [30-32]. While only mononuclear Pd(II) species could be unambiguously identified in the mass spectrum, the splitting of several peaks in both ${ }^{1} \mathrm{H}$ and ${ }^{13} \mathrm{C}$ NMR is consistent with formation of a dimer, present in both cisoid and transoid forms. 


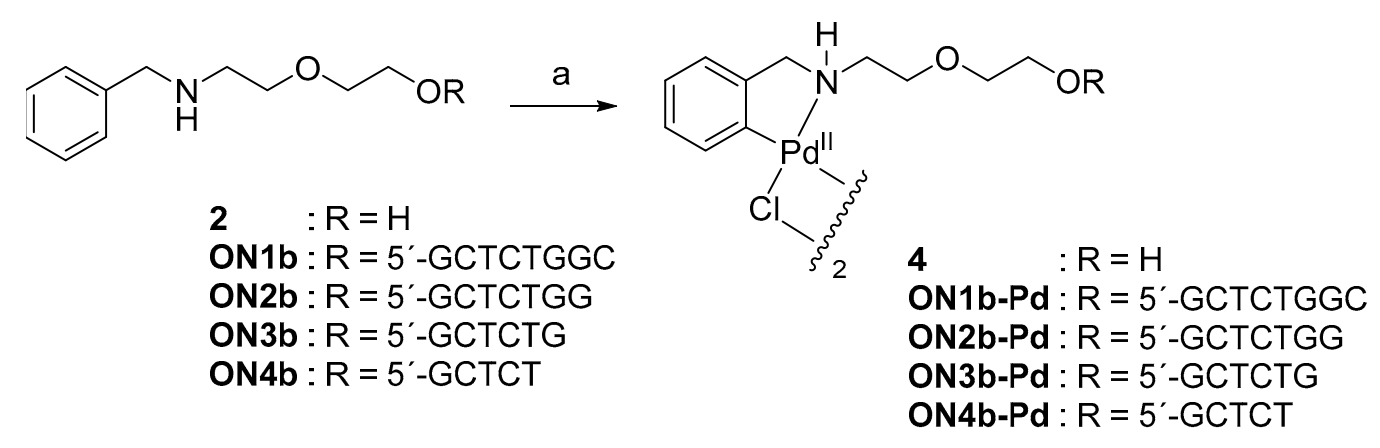

Scheme 2. Cyclopalladation of 2-[2-(benzylamino)ethoxy]ethanol (2) and the corresponding modified oligonucleotides $\mathbf{O N 1 b}, \mathbf{O N 2 b}, \mathbf{O N} 3 \mathbf{b}$ and $\mathbf{O N} 4 \mathbf{b}$. Reagents and conditions: a) $\mathrm{Li}_{2} \mathrm{PdCl}_{4}, \mathrm{MeCN}_{2} \mathrm{H}_{2} \mathrm{O}$, $25^{\circ} \mathrm{C}, 16 \mathrm{~h}$.

\subsection{Oligonucleotide Synthesis}

The sequences of the oligonucleotides used in the present study are summarised in Table 1. Synthesis of the modified oligonucleotides $\mathbf{O N} 1 \mathbf{b}, \mathbf{O N} 2 \mathbf{b}, \mathbf{O N} 3 \mathbf{b}$ and $\mathbf{O N} 4 \mathbf{b}$, having a $5^{\prime}$-terminal benzylamine moiety, was carried out on an automated DNA synthesizer using conventional phosphoramidite strategy. Treatment with concentrated aq. ammonia was employed for removal of the base and phosphate protections and release of the oligonucleotides from the solid support. Cyclopalladation of oligonucleotides $\mathbf{O N} 1 \mathbf{b}, \mathbf{O N} 2 \mathbf{b}, \mathbf{O N} 3 \mathbf{b}$ and $\mathbf{O N} 4 \mathbf{b}$ was carried out as described above for the monomer 2 (Scheme 2), except that 2.0 equivalents of lithium tetrachloropalladate was used. All modified oligonucleotides were purified by reversed-phase high performance liquid chromatography (RP-HPLC), characterized by electrospray ionization mass spectrometry (ESI-MS) and quantified by UV spectrophotometry.

Table 1. Oligonucleotides used in this study.

\begin{tabular}{|c|c|}
\hline Oligonucleotide & Sequence $^{1}$ \\
\hline ON1a & $5^{\prime}$ - $\underline{\text { AGCTCTGGC-3' }}$ \\
\hline ON2a & $5^{\prime}$ - $\underline{\mathrm{A}} \mathrm{GCTCTGG}-3^{\prime}$ \\
\hline ON3a & $5^{\prime}$-AGGCTCTG-3' \\
\hline ON4a & $5^{\prime}-\underline{-\bar{A}}$ GCTCT- $3^{\prime}$ \\
\hline ON1b & $5^{\prime}$-BGGCTCTGGC- $3^{\prime}$ \\
\hline ON2b & $5^{\prime}-\underline{\bar{B}} \mathrm{GCTCTGG}-3^{\prime}$ \\
\hline ON3b & $5^{\prime}-\overline{\mathrm{B}} \mathrm{GCTCTG}-3^{\prime}$ \\
\hline ON4b & $5^{\prime}-\underline{-}$ GCTCT- $3^{\prime}$ \\
\hline ON1b-Pd & $5^{\prime}-\mathrm{B}^{\mathrm{Pd}}$ GCTCTGGC $-3^{\prime}$ \\
\hline ON2b-Pd & $5^{\prime}-\overline{\mathrm{B}^{\mathrm{Pd}}}$ GCTCTGG-3' \\
\hline ON3b-Pd & $5^{\prime}-\overline{\mathrm{B}^{\mathrm{Pd}}}$ GCTCTG-3' \\
\hline ON4b-Pd & $5^{\prime}-\underline{\mathrm{B}^{\mathrm{Pd}}}$ GCTCT- $3^{\prime}$ \\
\hline ON5a & $5^{\prime}$-GCCAGAGCTCG-3' \\
\hline ON5c & 5'-GCCAGĒGCTCG-3' \\
\hline ON5g & $5^{\prime}$-GCCAGGGCTCG-3' \\
\hline ON5t & 5'-GCCAGT̄GCTCG-3' \\
\hline
\end{tabular}

${ }^{1} \mathrm{~B}$ refers to unmetalated and $\mathrm{B}^{\mathrm{Pd}}$ to cyclopalladated benzylamine residue. The residues varied in the hybridization studies have been underlined.

\subsection{Hybridization Studies}

The impact of the $5^{\prime}$-terminal palladacyclic "warheads" on the hybridization properties of short oligonucleotides was assessed by recording melting temperatures of duplexes formed by oligonucleotides $\mathbf{O N 1 b}-\mathbf{P d}, \mathbf{O N 2 b - P d}, \mathbf{O N 3 b - P d}$ and $\mathbf{O N} 4 \mathbf{b}-\mathbf{P d}$ with the natural counterparts $\mathbf{O N 2 a}$, ON2c, ON2g and ON2t. For reference, similar experiments were also carried out on respective 
duplexes formed by oligonucleotides ON1b, ON2b, ON3b, ON4b, ON1a, ON2a, ON3a and ON4a, having either an unmetalated benzylamine or an adenine residue at their $5^{\prime}$-termini. In all assemblies, the $5^{\prime}$-terminal residue was placed opposite to a thymine residue of a trinucleotide overhang of the complementary oligonucleotide (Figure 1). A single base pair within the double helical region, on the other hand, was varied to test the sensitivity of hybridization to a single-nucleotide mismatch. All experiments were performed at pH 7.4 (20 mM cacodylate buffer) and ionic strength of $0.10 \mathrm{M}$ (adjusted with sodium perchlorate) and each sample was first annealed by heating to $90{ }^{\circ} \mathrm{C}$ and then slowly cooling down to room temperature.

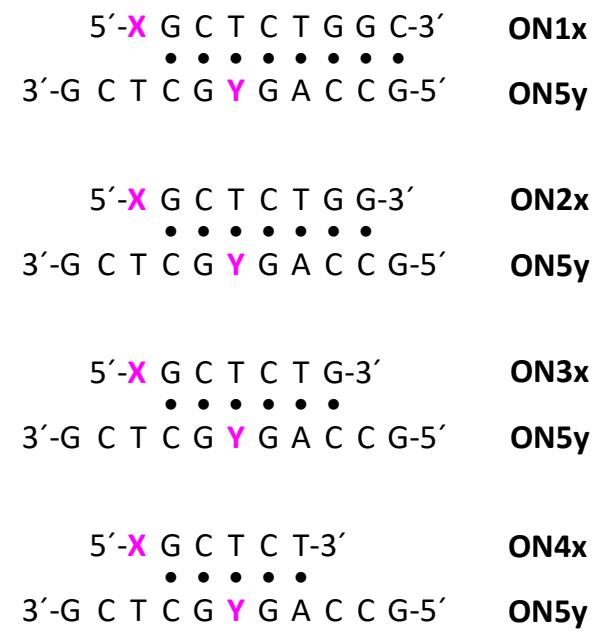

Figure 1. Outline of the hybridization assays used. $X$ is either adenine or unmetalated or cyclopalladated benzylamine and $\mathrm{Y}$ is any canonical nucleobase. The bullets indicate Watson-Crick base pairing.

The longest matched duplexes ON1x•ON5a all exhibited sigmoidal melting profiles, with $T_{\mathrm{m}}$ (melting temperature) values ranging from 36 to $41{ }^{\circ} \mathrm{C}$ (Figure $2 \mathrm{~A}-\mathrm{C}$ ). The shorter duplexes did not fully hybridize even at the lowest temperature applicable $\left(10^{\circ} \mathrm{C}\right)$ but their $T_{\mathrm{m}}$ values could still be determined with reasonable accuracy as inflection points of the melting curves. The melting temperatures of the mismatched duplexes, on the other hand, were high enough to be determined

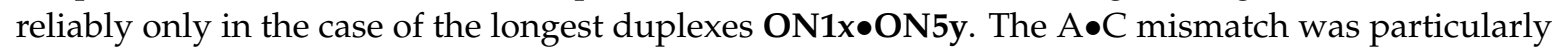
destabilizing and precluded determination of the $T_{m}$ in all cases, regardless of the length of the duplex. Melting temperatures are summarized in Figure 2D for the longest duplexes and in the Supplementary Materials for all duplexes.

Melting temperatures of the longest matched duplexes ON1a•ON5a, ON1b•ON5a and ON1b-Pd•ON5a, were $40.4 \pm 0.7^{\circ} \mathrm{C}, 35.8 \pm 0.6{ }^{\circ} \mathrm{C}$ and $41.0 \pm 0.6{ }^{\circ} \mathrm{C}$, respectively. In other words, the cyclopalladated benzylamine residue was modestly stabilizing relative to an adenine residue and strongly stabilizing relative to the unmetalated benzylamine residue. To explore the origin of this stabilization, the UV melting experiments were repeated in the presence of 2-mercaptoethanol $(100 \mu \mathrm{M})$. 2-Mercaptoethanol is a strong ligand for soft transition metal ions and would, hence, be expected to disrupt coordination of $\mathrm{Pd}(\mathrm{II})$ to nucleobases. If such coordination is important for duplex stability, a decrease in $\mathrm{T}_{\mathrm{m}}$ on addition of 2-mercaptoethanol should be observed.

Melting temperatures of the longest matching duplexes ON1x•ON5a in the absence and presence of 2-mercaptoethanol are presented in Figure 3 (all melting temperatures are presented in the Supporting Information). As expected, melting temperatures of duplexes ON1a•ON5a and

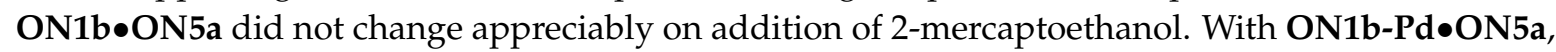
on the other hand, a clear drop in $T_{\mathrm{m}}$ was observed, consistent with stabilizing coordination of $\mathrm{Pd}(\mathrm{II})$ in the absence of competing ligands. 
A

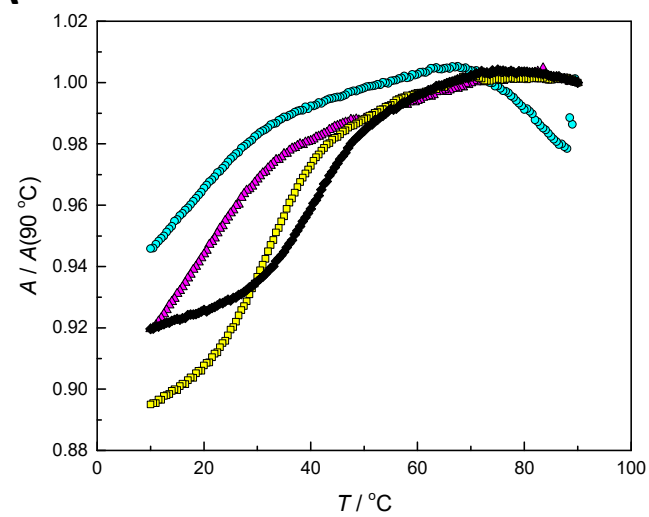

C

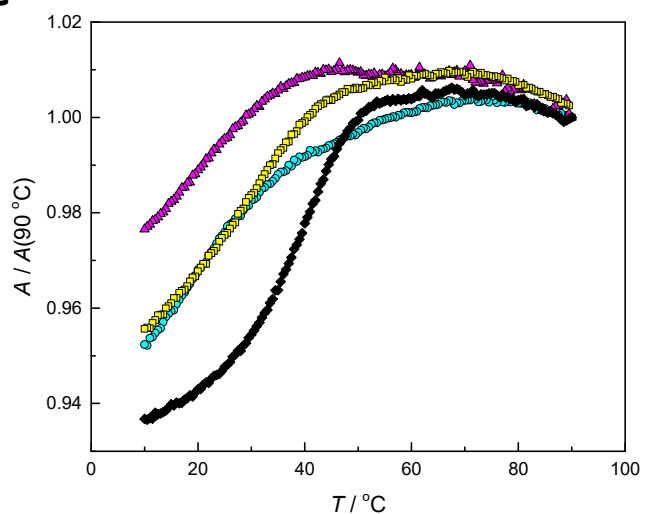

B

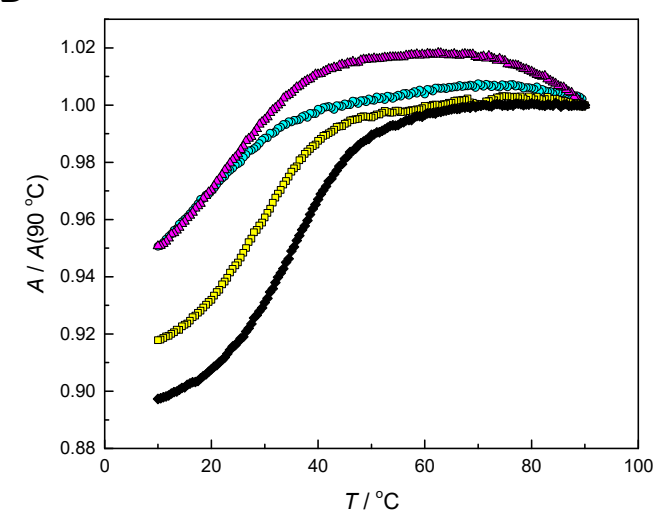

D

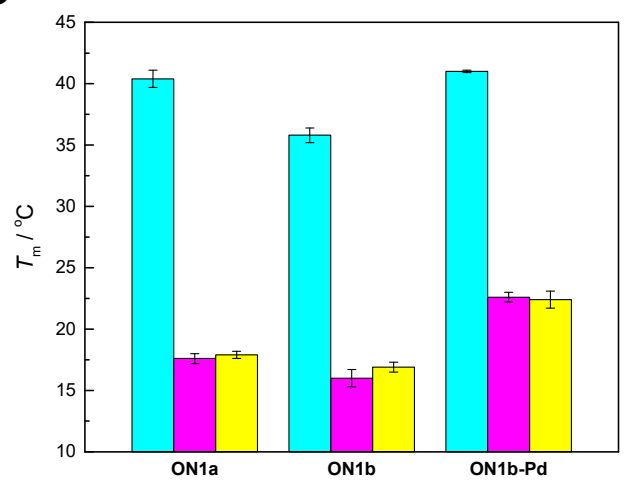

Figure 2. UV melting profiles for duplexes formed by ON5a with (A) ON1a (cyan circles), ON2a (magenta triangles), ON3a (yellow squares) and ON4a (black diamonds); (B) ON1b (cyan circles), ON2b (magenta triangles), ON3b (yellow squares) and ON4b (black diamonds) and (C) ON1b-Pd (cyan circles), ON2b-Pd (magenta triangles), ON3b-Pd (yellow squares) and ON4b-Pd (black diamonds); (D) melting temperatures of duplexes formed by ON1a, ON1b and ON1b-Pd with ON5a (cyan), ON5g (magenta) and ON5t (yellow); pH = 7.4 (20 mM cacodylate buffer); [oligonucleotides] $=3.0 \mu \mathrm{M} ;\left(\mathrm{NaClO}_{4}\right)=0.10 \mathrm{M}$. The error bars represent standard deviations of three independent measurements.

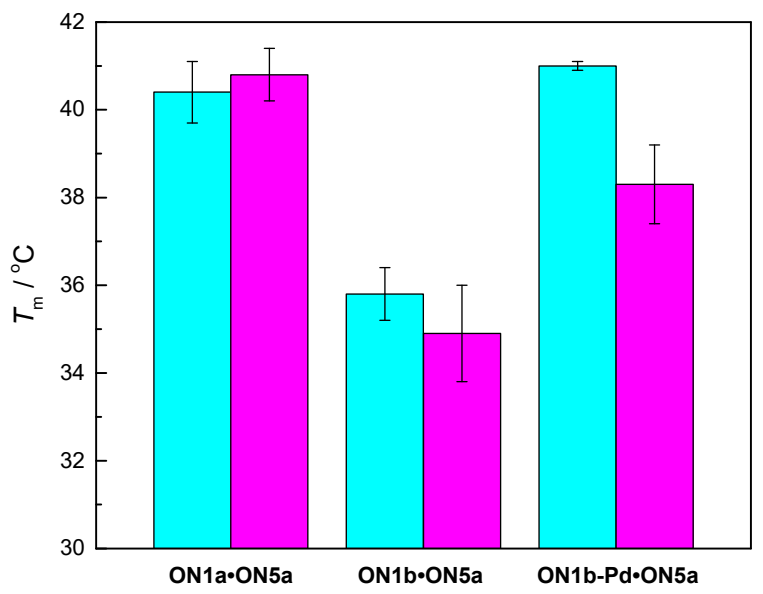

Figure 3. Melting temperatures of duplexes ON1a•ON5a, ON1b•ON5a and ON1b-Pd•ON5a in the absence (cyan) and presence (magenta) of 2-mercaptoethanol; $\mathrm{pH}=7.4$ (20 mM cacodylate buffer); [oligonucleotides] $=3.0 \mu \mathrm{M} ;[2$-mercaptoethanol $]=0 / 100 \mu \mathrm{M} ;\left(\mathrm{NaClO}_{4}\right)=0.10 \mathrm{M}$. The error bars represent standard deviations of three independent measurements. 
To further elucidate the role of the palladacyclic "warhead", a detailed thermodynamic analysis of

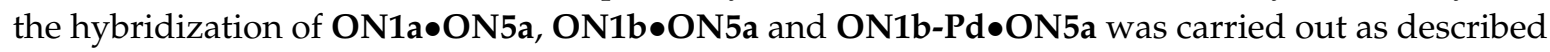
in the literature [33]. The resultant enthalpies and entropies of hybridization are presented in Table 2. With ON1b-Pd•ON5a, both values were significantly more negative than with ON1a•ON5a or ON1b•ON5a.

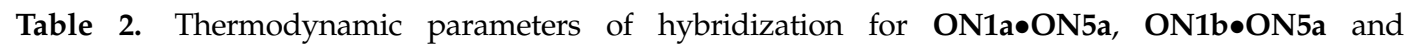
ON1b-Pd•ON5a; $\mathrm{pH}=7.4$ (20 mM cacodylate buffer); [oligonucleotides] = $3.0 \mu \mathrm{M} ;\left(\mathrm{NaClO}_{4}\right)=0.10 \mathrm{M}$.

\begin{tabular}{|c|c|c|}
\hline Duplex & $\Delta H^{\circ} / \mathrm{kJ} \cdot \mathrm{mol}^{-1}$ & $\Delta S^{\circ} / \mathrm{J} \cdot \mathrm{mol}^{-1} \cdot \mathrm{K}^{-1}$ \\
\hline ON1a•ON5a & $-200 \pm 20$ & $-530 \pm 50$ \\
\hline ON1b•ON5a & $-200 \pm 10$ & $-550 \pm 40$ \\
\hline ON1b-Pd•ON5a & $-250 \pm 20$ & $-670 \pm 50$ \\
\hline
\end{tabular}

Secondary structure of duplexes formed by the cyclopalladated oligonucleotides was studied $\mathrm{CD}$ spectropolarimetrically over a temperature range of $10-90{ }^{\circ} \mathrm{C}$ at $10{ }^{\circ} \mathrm{C}$ intervals. All the other conditions were identical to those of the UV melting experiments. With the longest matched duplexes, the spectra obtained at $10{ }^{\circ} \mathrm{C}$ were clearly characteristic of a B-type double helix, with prominent negative and positive signals at 260 and $280 \mathrm{~nm}$, respectively (Figure 4 for ON1b-Pd•ON5a, all spectra are presented in the Supplementary Materials). Similar, but weaker, signals were observed with the shorter and/or mismatched duplexes, reflecting their lower melting temperatures. In all cases, the signals diminished on increasing temperature, consistent with unwinding of the double helix.

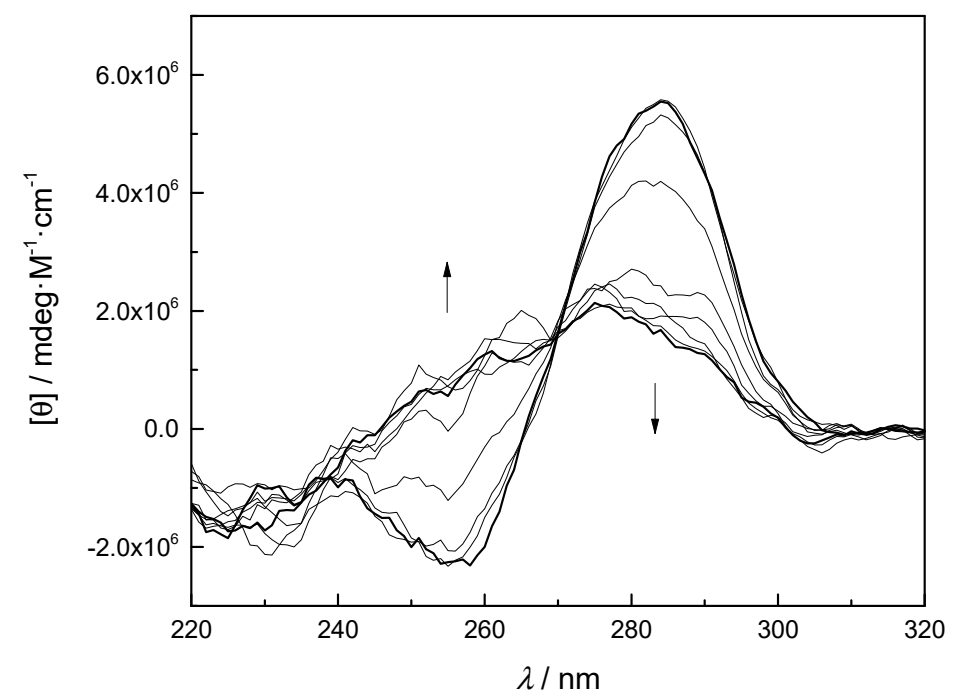

Figure 4. CD (circular dichroism) spectra of ON1b-Pd•ON5a, recorded at $10{ }^{\circ} \mathrm{C}$ intervals between 10 and $90{ }^{\circ} \mathrm{C} ; \mathrm{pH}=7.4(20 \mathrm{mM}$ cacodylate buffer $)$; [oligonucleotides] $=3.0 \mu \mathrm{M} ; \mathrm{I}\left(\mathrm{NaClO}_{4}\right)=0.10 \mathrm{M}$. Spectra acquired at extreme temperatures are indicated by thicker lines and thermal shifts of the minima and maxima by arrows.

\section{Discussion}

\subsection{Duplex Stabilization by the Palladacyclic "Warhead"}

The sensitivity of the duplex stabilization by the cyclopalladated benzylamine moiety to the presence of 2-mercaptoethanol suggests direct coordination of $\mathrm{Pd}(\mathrm{II})$ to a base moiety of the complementary strand. The thymine base directly opposite to the palladacyclic residue appears as the most likely candidate but, given the length and flexibility of the diethylene glycol linker, coordination 
to other bases of the $3^{\prime}$-overhang cannot be ruled out. The most likely donor atoms within these bases are the $\mathrm{N} 3$ of cytosine and thymine and the $\mathrm{N} 1$ of guanine [34-36].

Duplex stabilization by the cyclopalladated benzylamine moiety is rather modest when compared to stabilizations achieved previously with metal mediated base pairing [37-46]. One should, however, bear in mind that within a double helix the most stable metal mediated base pairs are formed between two nucleosides or nucleoside analogues, preorganized to place the donor atoms at appropriate positions. In the present case the flexible diethylene glycol linker first has to adopt a conformation conducive to $\mathrm{Pd}(\mathrm{II})$ coordination, consistent with the observed highly negative entropy of hybridization. As a result, the stabilizing enthalpic contribution by $\mathrm{Pd}(\mathrm{II})$ coordination is almost entirely offset by the entropic penalty.

\subsection{Impact of the Palladacyclic "Warhead" on Sequence Selectivity}

Highly stabilizing modifications are known to be able to override sequence information and allow hybridization of even highly mismatched oligonucleotides [47]. Even in the present case, the mismatched duplexes were actually stabilized more than the matched ones by the cyclopalladated benzylamine moiety. However, the difference in $T_{\mathrm{m}}$ between the matched and the most stable

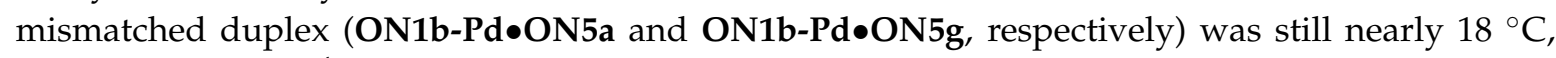
translating into a $10^{4}$-fold preference of ON5a over ON5g in hybridization with ON1b-Pd.

\section{Materials and Methods}

\subsection{General Methods}

NMR spectra were recorded on Bruker 500 NMR spectrometers (Bruker, Billerica, MA, USA) and chemical shifts $(\delta, \mathrm{ppm})$ are quoted relative to the residual solvent peak as an internal standard. Mass spectra were recorded on a Bruker Daltonics microTOF-Q mass spectrometer (Bruker, Billerica, MA, USA). The solvents for organic synthesis were of reagent grade and dried over $4 \AA$ molecular sieves. For preparation of HPLC elution buffers, freshly distilled triethylamine was used. The other chemicals, including unmodified oligonucleotides, were commercial products that were used as received.

\subsection{N-benzyl-2,2,2-trifluoro-N-[2-(2-hydroxyethoxy)ethyl]acetamide (3)}

2-[2-(benzylamino)ethoxy]ethanol (2, $2.00 \mathrm{~g}, 10.2 \mathrm{mmol})$ was dissolved in $\mathrm{MeOH}(10 \mathrm{~mL})$. $\mathrm{Et}_{3} \mathrm{~N}(2.90 \mathrm{~mL}, 20.4 \mathrm{mmol})$ was added and the resulting mixture stirred for $30 \mathrm{~min}$ at $25{ }^{\circ} \mathrm{C}$. Ethyl trifluoroacetate $(1.46 \mathrm{~g}, 10.2 \mathrm{mmol})$ was then added and the reaction mixture stirred for $16 \mathrm{~h}$ at $25{ }^{\circ} \mathrm{C}$, after which it was evaporated to dryness to afford the desired product 3 as a mixture of two slowly interconverting rotamers $\left(2.98 \mathrm{~g}\right.$, near quantitative yield). ${ }^{1} \mathrm{H} \mathrm{NMR}\left(\mathrm{CDCl}_{3}, 500 \mathrm{MHz}\right.$, major rotamer): $\delta$ 7.19-7.48 (m, 5H), $4.80(\mathrm{~s}, 2 \mathrm{H}), 3.40-3.70(\mathrm{~m}, 8 \mathrm{H}), 2.82(\mathrm{br}, 1 \mathrm{H}) .{ }^{1} \mathrm{H}$ NMR $\left(\mathrm{CDCl}_{3}\right.$, $500 \mathrm{MHz}$, minor rotamer): $\delta$ 7.19-7.48 $(\mathrm{m}, 5 \mathrm{H}), 4.82(\mathrm{~s}, 2 \mathrm{H}), 3.40-3.70(\mathrm{~m}, 8 \mathrm{H}), 2.82(\mathrm{br}, 1 \mathrm{H})$. ${ }^{13} \mathrm{C} \mathrm{NMR}\left(\mathrm{CDCl}_{3}, 125 \mathrm{MHz}\right.$, major rotamer): $\delta 157.1(\mathrm{q}, J=35.8 \mathrm{~Hz}), 136.3,128.7,127.7,127.6$, $116.8(\mathrm{q}, J=285.9 \mathrm{~Hz}), 72.5,67.6,60.9,50.3,46.8(\mathrm{q}, J=2.9 \mathrm{~Hz}) .\left(\mathrm{CDCl}_{3}, 125 \mathrm{MHz}\right.$, minor rotamer): $\delta 156.9(\mathrm{q}, J=35.8 \mathrm{~Hz}), 135.8,128.8,127.9,127.2,116.8(\mathrm{q}, J=285.9 \mathrm{~Hz}), 72.4,68.9,61.0,51.4(\mathrm{q}, J=3.0 \mathrm{~Hz})$, 46.0. HRMS $\left(\mathrm{ESI}^{+}\right) \mathrm{m} / z$ calcd 314.0974 obsd $314.0972[\mathrm{M}+\mathrm{Na}]^{+}$.

\subsection{2-[2-(N-benzyl-2,2,2-trifluoroacetamido)ethoxy]ethyl 2-cyanoethyl N,N-diisopropylphosphoramidite (1)}

$\mathrm{N}$-benzyl-2,2,2-trifluoro- $\mathrm{N}$-(2-(2-hydroxyethoxy)ethyl)acetamide $(3,670 \mathrm{mg}, 2.30 \mathrm{mmol})$ and $\mathrm{Et}_{3} \mathrm{~N}(1.93 \mathrm{~mL}, 13.8 \mathrm{mmol})$ were dissolved in anhydrous $\mathrm{CH}_{2} \mathrm{Cl}_{2}(7 \mathrm{~mL})$ under $\mathrm{N}_{2}$ atmosphere. 2-Cyanoethyl $\mathrm{N}, \mathrm{N}$-diisopropylchlorophosphoramidite $(0.616 \mathrm{~mL}, 2.76 \mathrm{mmol})$ was added and the resulting mixture stirred for $3 \mathrm{~h}$ at $25{ }^{\circ} \mathrm{C}$, after which the reaction was quenched by addition of saturated aq. $\mathrm{NaHCO}_{3}(100 \mathrm{~mL})$. The phases were separated and the aqueous phase was extracted with $\mathrm{CH}_{2} \mathrm{Cl}_{2}(100 \mathrm{~mL})$. The combined organic phases were washed with saturated aq. $\mathrm{NaHCO}_{3}$ 
(100 mL), dried over anhydrous $\mathrm{Na}_{2} \mathrm{SO}_{4}$ and evaporated to dryness. The crude product thus obtained was passed through a silica gel column eluting with a mixture of EtOAc and hexane $(1: 1, v / v)$ to afford the desired product 1 containing a major impurity of 2-Cyanoethyl $\mathrm{N}, \mathrm{N}$-diisopropylphosphonamidate (859 mg, 72\% yield based on ${ }^{31} \mathrm{P}$ NMR). This material was used in oligonucleotide synthesis without further purification. ${ }^{1} \mathrm{H}$ NMR $\left(\mathrm{CDCl}_{3}, 500 \mathrm{MHz}\right.$, major rotamer): $\delta 7.22-7.48(\mathrm{~m}, 5 \mathrm{H}), 4.80(\mathrm{~s}, 2 \mathrm{H})$, 3.36-3.89 (m, 12H), $2.66(\mathrm{~m}, 2 \mathrm{H}), 1.20(\mathrm{~d}, J=6.8 \mathrm{~Hz}, 6 \mathrm{H}), 1.19(\mathrm{~d}, J=6.8 \mathrm{~Hz}, 6 \mathrm{H}) .{ }^{1} \mathrm{H} \mathrm{NMR}\left(\mathrm{CDCl}_{3}\right.$, $500 \mathrm{MHz}$, minor rotamer): $\delta$ 7.22-7.48 $(\mathrm{m}, 5 \mathrm{H}), 4.82(\mathrm{~s}, 2 \mathrm{H}), 3.36-3.89(\mathrm{~m}, 12 \mathrm{H}), 2.66(\mathrm{~m}, 2 \mathrm{H})$, $1.20(\mathrm{~d}, J=6.8 \mathrm{~Hz}, 6 \mathrm{H}), 1.19(\mathrm{~d}, J=6.8 \mathrm{~Hz}, 6 \mathrm{H}) .{ }^{13} \mathrm{C} \mathrm{NMR}\left(\mathrm{CDCl}_{3}, 125 \mathrm{MHz}\right.$, major rotamer $):$ $\delta 157.1(\mathrm{q}, J=36.0 \mathrm{~Hz}), 136.3,128.7,127.7,127.6,118.6,116.8(\mathrm{q}, J=288.2 \mathrm{~Hz}), 71.1(\mathrm{~d}, J=7.6 \mathrm{~Hz}), 67.8$, $62.6(\mathrm{~d}, J=16.8 \mathrm{~Hz}), 58.4(\mathrm{~d}, J=19.2 \mathrm{~Hz}), 50.3,46.7(\mathrm{q}, J=2.9 \mathrm{~Hz}), 42.9(\mathrm{~d}, J=12.6 \mathrm{~Hz}), 24.0(\mathrm{~d}, J=7.2 \mathrm{~Hz})$, 20.0. ${ }^{13} \mathrm{C} \mathrm{NMR}\left(\mathrm{CDCl}_{3}, 125 \mathrm{MHz}\right.$, minor rotamer): $\delta 156.7(\mathrm{q}, J=35.4 \mathrm{~Hz}), 135.7,129.0,127.9,127.2$, 118.0, $116.8(\mathrm{q}, J=288.7 \mathrm{~Hz}), 71.0(\mathrm{~d}, J=7.7 \mathrm{~Hz}), 69.1,62.7(\mathrm{~d}, J=17.1 \mathrm{~Hz}), 58.4(\mathrm{~d}, J=19.2 \mathrm{~Hz})$, $51.5(\mathrm{q}, J=3.2 \mathrm{~Hz}), 45.9,42.9(\mathrm{~d}, J=12.6 \mathrm{~Hz}), 24.0(\mathrm{~d}, J=7.2 \mathrm{~Hz}), 20.0(\mathrm{~d}, J=6.9 \mathrm{~Hz}) .{ }^{31} \mathrm{P} \mathrm{NMR}\left(\mathrm{CDCl}_{3}\right.$, $202 \mathrm{MHz}$, major rotamer): $\delta 148.1 .{ }^{31} \mathrm{P} \mathrm{NMR}\left(\mathrm{CDCl}_{3}, 202 \mathrm{MHz}\right.$, minor rotamer): $\delta$ 148.0. HRMS (ESI $\left.{ }^{+}\right)$ $m / z$ calcd 514.2053 obsd $514.2034[\mathrm{M}+\mathrm{Na}]^{+}$.

\subsection{Bis\{N-[2-(2-hydroxyethoxy)ethyl]benzylaminato- $\left.C^{2}, N\right\}$ bis( $\mu$-chloro) dipalladium(II) (4)}

2-[2-(benzylamino)ethoxy]ethanol $(2,240 \mathrm{mg}, 1.28 \mathrm{mmol})$ was dissolved in a mixture of $\mathrm{H}_{2} \mathrm{O}$ $(3 \mathrm{~mL})$ and $\mathrm{MeCN}(3 \mathrm{~mL}) . \mathrm{Li}_{2} \mathrm{PdCl}_{4}(336 \mathrm{mg}, 1.28 \mathrm{mmol})$ was dissolved in a mixture of $\mathrm{H}_{2} \mathrm{O}(10 \mathrm{~mL})$ and $\mathrm{MeCN}(10 \mathrm{~mL})$ and the resulting solution was added to the solution of 2 . After stirring for $16 \mathrm{~h}$ at $25{ }^{\circ} \mathrm{C}$, the reaction mixture was evaporated to dryness. The residue was purified by silica gel column chromatography eluting with a mixture of EtOAc and hexane $(8: 2, v / v)$, affording the desired

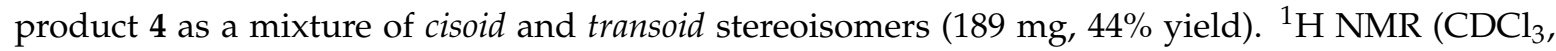
$500 \mathrm{MHz}$, major stereoisomer): $\delta 7.34-7.47(\mathrm{~m}, 4 \mathrm{H}), 4.46\left(\mathrm{ddd}, J_{1}=10.6 \mathrm{~Hz}, J_{2}=10.4 \mathrm{~Hz}, J_{3}=2.5 \mathrm{~Hz}\right.$, $1 \mathrm{H}), 4.28\left(\mathrm{dd}, J_{1}=13.1 \mathrm{~Hz}, J_{2}=6.7 \mathrm{~Hz}, 1 \mathrm{H}\right), 4.03(\mathrm{~m}, 1 \mathrm{H}), 3.44-3.80(\mathrm{~m}, 6 \mathrm{H}), 3.02(\mathrm{~m}, 1 \mathrm{H}), 2.38(\mathrm{~m}, 1 \mathrm{H})$. ${ }^{1} \mathrm{H}$ NMR (CDCl $3,500 \mathrm{MHz}$, minor stereoisomer): $87.34-7.47(\mathrm{~m}, 4 \mathrm{H}), 4.33(\mathrm{~m}, 1 \mathrm{H}), 4.24\left(\mathrm{dd}, J_{1}=13.0 \mathrm{~Hz}\right.$, $\left.J_{2}=7.6 \mathrm{~Hz}, 1 \mathrm{H}\right), 4.03(\mathrm{~m}, 1 \mathrm{H}), 3.44-3.80(\mathrm{~m}, 6 \mathrm{H}), 3.02(\mathrm{~m}, 1 \mathrm{H}), 2.38(\mathrm{~m}, 1 \mathrm{H}) .{ }^{13} \mathrm{C} \mathrm{NMR}\left(\mathrm{CDCl}_{3}, 125 \mathrm{MHz}\right.$, major stereoisomer): $\delta 147.5,135.0,129.9,129.7,128.9,128.6,72.8,67.8,61.6,57.35,50.8 .{ }^{13} \mathrm{C}$ NMR $\left(\mathrm{CDCl}_{3}, 125 \mathrm{MHz}\right.$, minor stereoisomer): $\delta$ 142.7, 135.2, 129.9, 129.7, 128.9, 128.6, 72.8, 67.6, 61.4, 57.26, 51.5. HRMS $\left(\mathrm{ESI}^{+}\right) \mathrm{m} / \mathrm{z}$ calcd 300.0216 obsd $300.0152\left[\mathrm{M} / 2-\mathrm{Cl}^{+}\right.$.

\subsection{Oligonucleotide Synthesis}

The modified oligonucleotides $\mathbf{O N 1 b}, \mathbf{O N} \mathbf{2} \mathbf{b}, \mathbf{O N} 3 \mathbf{b}$ and $\mathbf{O N} 4 \mathbf{b}$ were assembled on an Applied Biosystems 3400 (Applied Biosystems, Waltham, MA, USA) automated DNA/RNA synthesizer using conventional phosphoramidite strategy. For the benzylamine building block 1, an extended coupling time (600 s) was used. Removal of the base and phosphate protections and release of the oligonucleotides from the solid support was accomplished by treatment with $25 \%$ aq. $\mathrm{NH}_{3}$ for $16 \mathrm{~h}$ at $55{ }^{\circ} \mathrm{C}$. The cyclopalladated oligonucleotides ON1b-Pd, ON2b-Pd, ON3b-Pd and ON4b-Pd were prepared by incubating $\mathbf{O N 1 b}, \mathbf{O N} \mathbf{b}$, ON3b and ON4b (192, 260, 290 and $173 \mathrm{nmol}$, respectively) and $\mathrm{Li}_{2} \mathrm{PdCl}_{4}\left(384,520,580\right.$ and $346 \mathrm{nmol}$, respectively) in a mixture of $\mathrm{H}_{2} \mathrm{O}(530 \mu \mathrm{L})$ and $\mathrm{MeCN}(30 \mu \mathrm{L})$ for $16 \mathrm{~h}$ at $25{ }^{\circ} \mathrm{C}$. All modified oligonucleotides were purified by reversed-phase high performance liquid chromatography (RP-HPLC) on a Hypersil ODS C18 column $(250 \times 4.6 \mathrm{~mm}, 5 \mu \mathrm{m}$, Thermo Fisher Scientific, Waltham, MA, USA) eluting with a linear gradient ( 0 to $30 \%$ over $25 \mathrm{~min}$ ) of MeCN in $50 \mathrm{mM}$ aqueous triethylammonium acetate. The flow rate was $1.0 \mathrm{~mL} \cdot \mathrm{min}^{-1}$ and the detection wavelength $260 \mathrm{~nm}$. The purified oligonucleotides were characterized by electrospray ionization mass spectrometry (ESI-MS) and quantified UV spectrophotometrically using molar absorptivities calculated by an implementation of the nearest-neighbors method. Molar absorptivity of both free and cyclopalladated benzylamine was assumed to be negligible. 


\subsection{Melting Temperature Measurements}

Melting profiles were recorded on a PerkinElmer Lambda $35 \mathrm{UV}$-Vis spectrometer equipped with a Peltier temperature control unit (PerkinElmer, Waltham, MA, USA). Samples were prepared by mixing the appropriate oligonucleotides $(3.0 \mu \mathrm{M})$ in $20 \mathrm{mM}$ cacodylate buffer $(\mathrm{pH} 7.4)$, the ionic strength of which was adjusted to $0.10 \mathrm{M}$ with $\mathrm{NaClO}_{4}$. When applicable, 2-mercaptoethanol was used in $100 \mu \mathrm{M}$ concentration and added after mixing of the oligonucleotides. Before measurement, the samples were annealed by heating to $90^{\circ} \mathrm{C}$ and gradually cooling to room temperature. UV melting curves were acquired by monitoring the absorbance at $\lambda=260 \mathrm{~nm}$ over a temperature range of $10-90^{\circ} \mathrm{C}$, sampling at $10^{\circ} \mathrm{C}$ intervals. The melting temperatures were determined as inflection points on the UV melting curves.

\subsection{Measurements}

CD spectra were recorded on an Applied Photophysics Chirascan spectropolarimeter equipped with a Peltier temperature control unit (Applied Photophysics, Leatherhead, UK). Samples used in the CD measurements were identical to those used in the UV melting temperature measurements. $\mathrm{CD}$ spectra were acquired between $\lambda=200$ and $400 \mathrm{~nm}$ over a temperature range of $10-90{ }^{\circ} \mathrm{C}$, sampling at $10{ }^{\circ} \mathrm{C}$ intervals. At each temperature, samples were allowed to equilibrate for $600 \mathrm{~s}$ before acquisition.

\section{Conclusions}

Cyclopalladated benzylamine, tethered at a terminal position of a short oligonucleotide by a flexible linker, promotes hybridization despite a significant entropy penalty for "freezing" the linker in an appropriate conformation. Sensitivity to the presence of competing ligands suggests direct coordination of $\mathrm{Pd}(\mathrm{II})$ to a nucleobase of the complementary strand as the origin of stabilization by the palladacyclic moiety. In light of these results, oligonucleotides furnished with palladacyclic "warheads" could prove useful as a sequence-selective alternative to current platinum-based anticancer agents.

Supplementary Materials: Supplementary materials can be found at http:/ / www.mdpi.com/1422-0067/19/6/ 1588/s1.

Author Contributions: Conceptualization, T.L.; Methodology, T.L. and S.M.; Investigation, M.H. and S.M.; Resources, T.L.; Data Curation, T.L.; Writing-Original Draft Preparation, M.H. and T.L.; Writing-Review and Editing, T.L.; Visualization, T.L.; Supervision, T.L. and S.M.; Project Administration, T.L.; Funding Acquisition, T.L.

Funding: This project has received funding from the European Union's Horizon 2020 research and innovation programme under the Marie Skłodowska-Curie grant agreement No. 721613 and from the Academy of Finland (decisions No. 286478 and No. 294008).

Conflicts of Interest: The authors declare no conflict of interest.

\section{Abbreviations}

$\begin{array}{ll}\text { CD } & \text { circular dichroism } \\ \text { DNA } & \text { deoxyribonucleic acid } \\ \text { PNA } & \text { peptide nucleic acid } \\ \text { RP-HPLC } & \text { reversed-phase high performance liquid chromatography } \\ \text { ESI-MS } & \text { electrospray ionization mass spectrometry }\end{array}$

\section{References}

1. Dasari, S.; Tchounwou, P.B. Cisplatin in cancer therapy: Molecular mechanisms of action. Eur. J. Pharmacol. 2014, 740, 364-378. [CrossRef] [PubMed]

2. Rosenberg, B.; Van Camp, L.; Krigas, T. Inhibition of cell division in Escherichia coli by electrolysis products from a platinum electrode. Nature 1965, 205, 698-699. [CrossRef] [PubMed] 
3. Sanchez-Cano, C.; Hannon, M.J. Novel and emerging approaches for the delivery of metallo-drugs. Dalton Trans. 2009, 10702-10711. [CrossRef] [PubMed]

4. Ott, I.; Gust, R. Non platinum metal complexes as anti-cancer drugs. Arch. Pharm. 2007, 340, 117-126. [CrossRef] [PubMed]

5. Bruijnincx, P.C.A.; Sadler, P.J. New trends for metal complexes with anticancer activity. Curr. Opin. Chem. Biol. 2008, 12, 197-206. [CrossRef] [PubMed]

6. Ott, I. On the medicinal chemistry of gold complexes as anticancer drugs. Coord. Chem. Rev. 2009, 253, 1670-1681. [CrossRef]

7. Levina, A.; Mitra, A.; Lay, P.A. Recent developments in ruthenium anticancer drugs. Metallomics 2009, 1, 458-470. [CrossRef] [PubMed]

8. Berners-Price, S.J.; Filipovska, A. Gold compounds as therapeutic agents for human diseases. Metallomics 2011, 3, 863-873. [CrossRef] [PubMed]

9. Cutillas, N.; Yellol, G.S.; de Haro, C.; Vicente, C.; Rodríguez, V.; Ruiz, J. Anticancer cyclometalated complexes of platinum group metals and gold. Coord. Chem. Rev. 2013, 257, 2784-2797. [CrossRef]

10. Johnstone, T.C.; Suntharalingam, K.; Lippard, S.J. The next generation of platinum drugs: Targeted Pt(II) agents, nanoparticle delivery, and Pt(IV) prodrugs. Chem. Rev. 2016, 116, 3436-3486. [CrossRef] [PubMed]

11. Bindoli, A.; Rigobello, M.P.; Scutari, G.; Gabbiani, C.; Casini, A.; Messori, L. Thioredoxin reductase: A target for gold compounds acting as potential anticancer drugs. Coord. Chem. Rev. 2009, 253, 1692-1707. [CrossRef]

12. Kelland, L. The resurgence of platinum-based cancer chemotherapy. Nat. Rev. Cancer 2007, 7, 573-584. [CrossRef] [PubMed]

13. Hartmann, J.T.; Lipp, H.-P. Toxicity of platinum compounds. Expert Opin. Pharmacother. 2003, 4, 889-901. [CrossRef] [PubMed]

14. Daugaard, G.; Abildgaard, U. Cisplatin nephrotoxicity. A review. Cancer Chemother. Pharmacol. 1989, $25,1-9$. [CrossRef] [PubMed]

15. Johnstone, T.C.; Suntharalingam, K.; Lippard, S.J. Third row transition metals for the treatment of cancer. Philos. Trans. A Math. Phys. Eng. Sci. 2015, 373, 20140185. [CrossRef] [PubMed]

16. Carreira, M.; Calvo-Sanjuán, R.; Sanaú, M.; Marzo, I.; Contel, M. Organometallic palladium complexes with a water-soluble iminophosphorane ligand as potential anticancer agents. Organometallics 2012, 31, 5772-5781. [CrossRef] [PubMed]

17. Caires, A.C.F. Recent advances involving palladium (II) complexes for the cancer therapy. Anticancer Agents Med. Chem. 2007, 7, 484-491. [CrossRef] [PubMed]

18. Taube, H. Rates and mechanisms of substitution in inorganic complexes in solution. Chem. Rev. 1952, 50, 69-126. [CrossRef]

19. Lippert, B.; Miguel, P.J.S. Comparing Pt ${ }^{\mathrm{II}}$ - and PdII -nucleobase coordination chemistry: Why Pd ${ }^{\mathrm{II}}$ not always is a good substitute for $\mathrm{Pt}^{\mathrm{II}}$. Inorg. Chim. Acta 2018, 472, 207-213. [CrossRef]

20. Serrano, F.A.; Matsuo, A.L.; Monteforte, P.T.; Bechara, A.; Smaili, S.S.; Santana, D.P.; Rodrigues, T.; Pereira, F.V.; Silva, L.S.; Machado, J.; et al. A cyclopalladated complex interacts with mitochondrial membrane thiol-groups and induces the apoptotic intrinsic pathway in murine and cisplatin-resistant human tumor cells. BMC Cancer 2011, 11, 296. [CrossRef] [PubMed]

21. Marchán, V.; Grandas, A. Platinated oligonucleotides: Synthesis and applications for the control of gene expression. In Metal Complex-DNA Interactions; John Wiley \& Sons, Ltd.: Hoboken, NJ, USA, 2009; pp. 273-300. [CrossRef]

22. Colombier, C.; Lippert, B.; Leng, M. Interstrand cross-linking reaction in triplexes containing a monofunctional transplatin-adduct. Nucleic Acids Res. 1996, 24, 4519-4524. [CrossRef] [PubMed]

23. Brabec, V.; Reedijk, J.; Leng, M. Sequence-dependent distortions induced in DNA by monofunctional platinum(II) binding. Biochemistry 1992, 31, 12397-12402. [CrossRef] [PubMed]

24. Algueró, B.; Pedroso, E.; Marchán, V.; Grandas, A. Incorporation of two modified nucleosides allows selective platination of an oligonucleotide making it suitable for duplex cross-linking. J. Biol. Inorg. Chem. 2007, 12, 901-911. [CrossRef] [PubMed]

25. Algueró, B.; López de la Osa, J.; González, C.; Pedroso, E.; Marchán, V.; Grandas, A. Selective platination of modified oligonucleotides and duplex cross-links. Angew. Chem. Int. Ed. 2006, 45, 8194-8197. [CrossRef] [PubMed] 
26. Schmidt, K.S.; Boudvillain, M.; Schwartz, A.; van der Marel, G.A.; van Boom, J.H.; Reedijk, J.; Lippert, B. Monofunctionally trans-diammine platinum(II)-modified peptide nucleic acid oligomers: A new generation of potential antisense drugs. Chem. Eur. J. 2002, 8, 5566-5570. [CrossRef]

27. Maity Sajal, K.; Lönnberg, T. Oligonucleotides incorporating palladacyclic nucleobase surrogates. Chem. Eur. J. 2018, 24, 1274-1277. [CrossRef] [PubMed]

28. Ruiz, J.; Cutillas, N.; Vicente, C.; Villa, M.D.; López, G.; Lorenzo, J.; Avilés, F.X.; Moreno, V.; Bautista, D. New palladium(II) and platinum(II) complexes with the model nucleobase 1-methylcytosine: Antitumor activity and interactions with DNA. Inorg. Chem. 2005, 44, 7365-7376. [CrossRef] [PubMed]

29. Ruiz, J.; Lorenzo, J.; Vicente, C.; López, G.; López-de-Luzuriaga, J.M.; Monge, M.; Avilés, F.X.; Bautista, D.; Moreno, V.; Laguna, A. New palladium(II) and platinum(II) complexes with 9-aminoacridine: Structures, luminiscence, theoretical calculations, and antitumor activity. Inorg. Chem. 2008, 47, 6990-7001. [CrossRef] [PubMed]

30. Fuchita, Y.; Tsuchiya, H. Synthesis of ortho-palladated complexes of n-methylbenzylamine: The first example of ortho-palladation of $\alpha$-unsubstituted secondary benzylamine. Inorg. Chim. Acta 1993, 209, 229-230. [CrossRef]

31. Fuchita, Y.; Tsuchiya, H.; Miyafuji, A. Cyclopalladation of secondary and primary benzylamines. Inorg. Chim. Acta 1995, 233, 91-96. [CrossRef]

32. Selvakumar, K.; Vancheesan, S. Synthesis and characterization of cyclopalladated complexes of secondary benzylamines. Polyhedron 1997, 16, 2405-2411. [CrossRef]

33. Mergny, J.-L.; Lacroix, L. Analysis of thermal melting curves. Oligonucleotides 2003, 13, 515-537. [CrossRef] [PubMed]

34. Golubev, O.; Lönnberg, T.; Lönnberg, H. Interaction of $\mathrm{Pd}^{2+}$ complexes of 2,6-disubstituted pyridines with nucleoside 5'-monophosphates. J. Inorg. Biochem. 2014, 139, 21-29. [CrossRef] [PubMed]

35. Martin, R.B. Nucleoside sites for transition metal ion binding. Acc. Chem. Res. 1985, 18, 32-38. [CrossRef]

36. Pneumatikakis, G.; Hadjiliadis, N.; Theophanides, T. Complexes of inosine, cytidine, and guanosine with palladium(II). Inorg. Chem. 1978, 17, 915-922. [CrossRef]

37. Scharf, P.; Müller, J. Nucleic acids with metal-mediated base pairs and their applications. ChemPlusChem 2013, 78, 20-34. [CrossRef]

38. Takezawa, Y.; Shionoya, M. Metal-mediated DNA base pairing: Alternatives to hydrogen-bonded Watson-Crick base pairs. Acc. Chem. Res. 2012, 45, 2066-2076. [CrossRef] [PubMed]

39. Clever, G.H.; Kaul, C.; Carell, T. DNA-metal base pairs. Angew. Chem. Int. Ed. 2007, 46, 6226-6236. [CrossRef] [PubMed]

40. Clever, G.H.; Shionoya, M. Metal-base pairing in DNA. Coord. Chem. Rev. 2010, 254, 2391-2402. [CrossRef]

41. Müller, J. Chemistry: Metals line up for DNA. Nature 2006, 444, 698. [CrossRef] [PubMed]

42. Müller, J. Metal-ion-mediated base pairs in nucleic acids. Eur. J. Inorg. Chem. 2008, 2008, 3749-3763. [CrossRef]

43. Mandal, S.; Müller, J. Metal-mediated DNA assembly with ligand-based nucleosides. Curr. Opin. Chem. Biol. 2017, 37, 71-79. [CrossRef] [PubMed]

44. Takezawa, Y.; Müller, J.; Shionoya, M. Artificial DNA base pairing mediated by diverse metal ions. Chem. Lett. 2017, 46, 622-633. [CrossRef]

45. Lippert, B.; Sanz Miguel, P.J. The renaissance of metal-pyrimidine nucleobase coordination chemistry. Acc. Chem. Res. 2016, 49, 1537-1545. [CrossRef] [PubMed]

46. Taherpour, S.; Golubev, O.; Lönnberg, T. On the feasibility of recognition of nucleic acid sequences by metal-ion-carrying oligonucleotides. Inorg. Chim. Acta 2016, 452, 43-49. [CrossRef]

47. Clever, G.H.; Söltl, Y.; Burks, H.; Spahl, W.; Carell, T. Metal-salen-base-pair complexes inside DNA: Complexation overrides sequence information. Chem. Eur. J. 2006, 12, 8708-8718. [CrossRef] [PubMed]

(C) 2018 by the authors. Licensee MDPI, Basel, Switzerland. This article is an open access article distributed under the terms and conditions of the Creative Commons Attribution (CC BY) license (http:/ / creativecommons.org/licenses/by/4.0/). 